\title{
Sodium Tetraphenylborate Catalyst Identification: Phase B and C Statistical Design Studies
}

by

M. J. Barnes

Westinghouse Savannah River Company

Savannah River Site

Aiken, South Carolina 29808

R. A. Peterson

This paper was prepared in connection with work done under the above contract number with the U.S. Department of Energy. By acceptance of this paper, the publisher and/or recipient acknowledges the U. S. Government's right to retain a nonexclusive, royalty-free license in and to any copyright covering this paper, along with the right to reproduce and to authorize others to reproduce all or part of the copyrighted paper. 


\section{DISCLAMMER}

This report was prepared as an account of work sponsored by an agency of the United States Government. Neither the United States Government nor any agency thereof, nor any of their employees, makes any warranty, express or implied, or assumes any legal liability or responsibility for the accuracy, completeness, or usefulness of any information, apparatus, product, or process disclosed, or represents that its use would not infringe privately owned rights. Reference herein to any specific commercial product, process, or service by trade name, trademark, manufacturer, or otherwise does not necessarily constitute or imply its endorsement, recommendation, or favoring by the United States Government or any agency thereof. The views and opinions of authors expressed herein do not necessarily state or reflect those of the United States Government or any agency thereof.

This report has been reproduced directly from the best available copy.

Available to DOE and DOE contractors from the Office of Scientific and Technical Information, P. O. Box 62, Oak Ridge, TN 37831; prices available from (423) 576-8401.

Available to the public from the National Technical Information Service, U. S. Department of Commerce, 5285. Port Royal Road, Springfield, VA 22161. 


\section{DISCLAIMER}

Portions of this document may be illegible in electronic image products. Images are produced from the best available original document. 
WSRC-TR-97-0230, Rev. 0

SODIUM TETRAPHENYLBORATE CATALYST IDENTIFICATION: PHASE B AND C STATISTICAL DESIGN STUDIES (U)

M. J. Barnes

R. A. Peterson

Publication Date: August 13, 1997

Westing ho use Sa va nna $h$ River Company

Savannah River Technology Center

Aiken, SC 29808

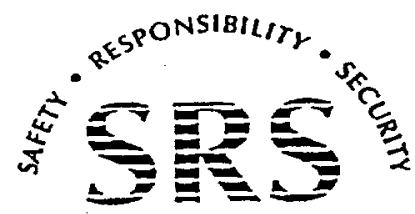

SAVANNAH RIVER SITE 
Sodium Tetraphenylborate Catalyst Identification:

Phase B and C Statistical Design Studies (U)

\section{Author}

Mll. Han

M. J. Marnes, Waste Processing Technology

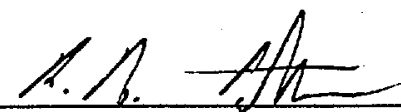

R. A. Peterson, Waste Processing Technology

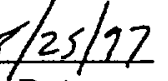

Date

Date

\section{Design Check}

Aarrel A. Nalken 8/25/97

D. D. Walker, Waste Processing Technology

(per Manual E7, Procedure 2.40)

\section{Approvals}

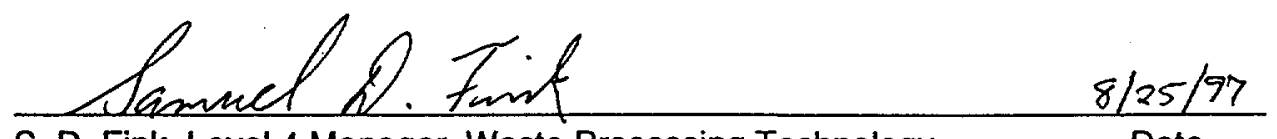

S. D. Fink, Level 4 Manager, Waste Processing Technology Date
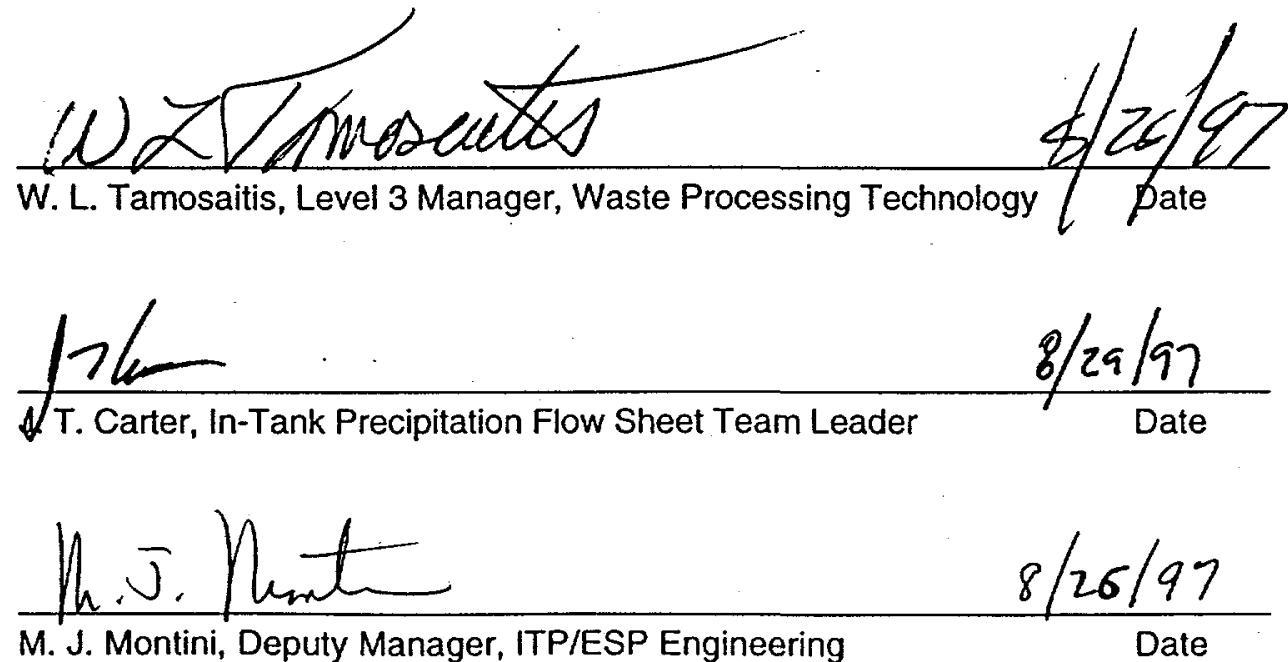


\subsection{Summary}

Excess sodium tetraphenylborate decomposed during startup of the In-Tank Precipitation process in 1995. Several tasks, in response to this event, resulted. This work supports resolution of DNFSB Recommendation 96-1 and partially fulfills the task to identify the catalyst responsible for the decomposition. Phases $\mathrm{B}$ and $\mathrm{C}$ of the statistical design soluble sodium tetraphenylborate decomposition catalyst identification tests are complete. Observations and conclusions drawn from Phase $\mathrm{B}$ and $\mathrm{C}$ testing follow.

- All three organic species (i.e., benzene, diphenylmercury, and phenylborate intermediates) are necessary to facilitate the observed rapid decomposition of soluble sodium tetraphenylborate.

- The decomposition reaction appears zero order with respect to the organic grouping; however, their large molar ratio (with respect to palladium) prevents determining this value with any certainty.

- An increasing benzene concentration (at low concentrations) speeds the reaction (i.e., reaction not zero order with respect to benzene). However, the tests could not determine the minimum benzene concentration required to promote reaction, although a benzene concentration of 360 $\mathrm{mg} / \mathrm{L}$ (i.e., the amount added in centerpoint Tests 61 and 62) does produce near-maximum rate constants.

- Palladium is the noble metal species responsible for the observed rapid decomposition. Rhodium, ruthenium, and silver proved inactive.

- A limited number of centerpoint tests suggested a reaction order less than unity with respect to palladium.

- A slow but statistically significant reaction (average $k^{\prime}=2.4 \pm 1.0 \mathrm{E}-4 \mathrm{~h}^{-1}$ ) occurred in a small number of tests. This rate appears consistent with reaction due to copper catalysis.

\subsection{Introduction}

Excess sodium tetraphenylborate (NaTPB) decomposed during startup of the In-Tank Precipitation (ITP) process in 1995. [Ref. 1] Several tasks, in response to this event, resulted. One task seeks to identify the catalyst responsible for the decomposition. [Ref. 2] The task includes two portions: preliminary tests and statistically designed tests. Previous reports give the results of the preliminary tests. [Ref. 3, 4] These tests assessed the relative influence of reaction conditions (for example, reaction vessel, agitation, salt solution composition, and insoluble tetraphenylborate). Results from preliminary tests defined the best conditions for subsequent statistical design tests. [Ref. 3, 4]

The statistical design tests focus on identifying key NaTPB decomposition catalysts. These designed tests, evolutionary in nature, include several phases. Thirty-six chemicals comprised the list of potential catalysts. Phase A segregated potential catalysts to differentiate between types (e.g., suspect active organics, suspect active metals, copper, etc.) of species. [Ref. 5] This segregation reduced the number of tests and determined that the interaction of a select group of organic compounds (i.e., benzene, diphenylmercury, triphenylborane, diphenylborinic acid, and phenylboronic acid, previously referred to suspect active organics) with a select group of metals (i.e., rhodium, ruthenium, palladium, and silver, previously referred to as suspect active metals) as responsible for the observed catalytic decomposition. Phase A tests demonstrated that a large number of the species found in ITP waste proved catalytically insignificant (relative to the aforementioned interaction). Table 1 contains a list of all inactive species tested as well as the two suspect active groups. The concentrations listed represent values measured in samples from Tank $48 \mathrm{H}$ during the 1995 reaction. The inclusion of all chemical species (except oxygen) provides a "fully-loaded" simulant of the ITP waste and, thus, should mimic the ITP NaTPB reaction. We term this simulant the Enhanced Comprehensive Catalyst, or ECC. Previous studies evaluated the reaction rates for this system. [Ref. 3 - 4] 
Phase A results prompted two additional sets (Phases $B$ and $C$ ) of statistically designed tests. The Phase $B$ design separates the five suspect active organics into three groups: benzene, phenylborate intermediates (i.e., triphenylborane, diphenylborinic acid, and phenylboronic acid), and diphenylmercury. The Phase $C$ design separates the four suspect active metals into individual species (i.e., palladium, rhodium, ruthenium, and silver). This document describes the results of Phase $B$ and $C$ statistically designed tests and is the fourth report for this task [Ref. 2] designed to identify soluble NaTPB decomposition catalysts. This task, performed as part of the Defense Nuclear Facility Safety Board (DNFSB) Recommendation 96-1 Implementation Plan [Ref. 6], partially fulfills the request by High Level Waste Engineering (HLWE) and the ITP Flow Sheet Team as defined in Task Technical Request HLWTTR-97008. [Ref. 7]

\subsection{Experimental}

\subsection{Statistical Design}

The design of Phase B tests sought to identify the specific compound(s) in the group of suspect active organics responsible for NaTPB catalytic decomposition. The tests segregated the five members of the suspect active organics into three fractions (i.e., benzene, diphenylmercury, and phenylborate intermediates). Three fractions were selected for three reasons. First, this design permitted a full factorial design with a minimal number of tests. Secondly, personnel thought that the three fractions performed distinct mechanistic functions. Third, facility personnel can exert a degree of control over selected fractions with respect to plant operation (e.g., pump operation can remove benzene from Tank $48 \mathrm{H}$ ). Table 2 shows the Phase B statistical design. The tests add all of the additional ECC components, including the four suspect active metals, to each Phase B test at their ECC concentrations. The table uses three values $(1,0,-1)$ to signify inclusion of the organic species at a representative concentration, one half of the representative concentration, or absent from the test, respectively. This statistical design examines all primary, secondary, and tertiary interactions. Phase B consists of eight statistically designed tests and two centerpoint tests.

The Phase $\mathrm{C}$ test design allows identification of the specific compound(s) in the group of suspect active metals responsible for NaTPB catalytic decomposition. The design segregated the suspect active metals group into individual components (i.e., ruthenium, rhodium, palladium, and silver). Table 3 shows the statistical design. This partial factorial design permits only identification of primary interactions. Since secondary and tertiary interactions between the metals seem unlikely, unlike with the suspect active organics, a fractional design is adequate. The tests add all of the additional ECC components, including the five suspect active organics, to each Phase $C$ test at their ECC concentrations. The table uses three values $(1,0,-1)$ to signify inclusion of the metal species at a representative concentration, one half of the representative concentration, or absent from the test, respectively. Phase $\mathrm{C}$ consists of eight statistically designed tests and two centerpoint tests.

\subsection{Reaction Conditions}

Tests used non-radioactive simulants. Solutions were prepared from reagent grade chemicals by weighing on calibrated balances. The accuracy of glassware used to measure volumes was verified by gravimetric methods using water as a standard. [Ref. 8] Temperature measurements used thermometers calibrated by the SRTC Standards Laboratory. Temperature monitoring occurred at least once per day. The temperature targeted $\pm 3^{\circ} \mathrm{C}$ of the stated set point. All additional measuring and test equipment used in this task received calibration or verification for accuracy prior to use.

As noted above, Table 1 lists the concentration of ECC components. Tables 2 and 3 provide a list of the statistical designs (i.e., which tests include which groups of potential catalysts or factors). Typically, tests were monitored over two weeks. Based upon conclusions drawn from preliminary test results (Ref. 3 and 4), all tests occurred in sealed $160-\mathrm{mL}$ glass serum bottles at $55^{\circ} \mathrm{C}$ with a nitrogen atmosphere. Each test used $2.7 \mathrm{M} \mathrm{Na}^{+}, 48 \mathrm{~g} / \mathrm{L} \mathrm{KTPB}$ slurry containing only soluble NaTPB (i.e., no NaTPB solids). Each bottle 
was charged with $100 \mathrm{~mL}$ of the simulant slurry (see Table 4) followed by a prescribed amount of each of the ECC components. The soluble metal species came from stock solutions prepared from common salts. For the insoluble solids, the tests used simulated Purex sludge that did not contain noble metals, copper, silver, or mercury. All tests requiring simulated sludge and MST added hydrated species. The soluble organic species (i.e., triphenylborane (3PB), diphenylborinic acid (2PB), phenylboronic acid (1PB), phenol, isopropanol, and methanol) came from an alkaline stock solution. Monosodium titanate (MST), benzene, diphenylmercury, and biphenyl were added as pure compounds. After adding all potential catalysts, each vessel was sealed.

In all tests, an initial (obtained immediately after sealing each vessel) filtrate sample was analyzed by High Performance Liquid Chromatography (HPLC) to obtain starting concentrations of NaTPB, 3PB, and $2 \mathrm{~PB}$. No analyses for benzene, 1PB, phenol, or soluble boron analysis occurred. Furthermore, only TPB; triphenylborane, and diphenylborinic acid species were monitored in subsequent samples: Filtrate was obtained for analysis by using syringe filter discs with a $0.45 \mu$ nominal pore size to remove solids from the slurry sample. Periodic analysis of the reaction mixtures occurred during the remainder of the testing. Slurry sampling occurred after aggressive, manual shaking for approximately 15 seconds. HPLC analysis of the filtrate from these samples allowed determination of the rate and extent of reaction. The tetraphenylborate ion (TPB') reaction rate represents the TPB- loss per unit time.

\subsection{Results and Discussion}

Tables 5 through 24 contain concentration data for NaTPB, 3PB, and 2PB for Tests 53 through 72, respectively. Sections 4.1 through 4.4 discuss the significance of the data.

\subsection{Reaction Rates and Rate Constants}

Reaction rates for Tests 53 through 72 were calculated based only on measured soluble NaTPB concentrations from samples taken throughout the reaction period (Equation 1). The calculations used Microsof ${ }^{\oplus}$ Excel 5.0 for data regression analysis. Kinetic calculations yielded pseudo first-order rate constants for each reaction. Changes in the concentrations of soluble decomposition products (i.e., 3PB and $2 \mathrm{~PB}$ ) during the two weeks of testing verify that differences $( \pm 10 \%)$ in NaTPB concentration reflect either decomposition or error in analysis. Since decomposition of NaTPB results in the production of 3PB and eventually 2PB, these measurements provide a confirmation of NaTPB decomposition (i.e., 3PB and 2PB measurements help determine if an observed change or observed variability in NaTPB reflects decomposition or analytical error). Table 25 lists pseudo first-order rate constants for Tests 53 through 72 . Sections 4.2 through 4.4 provide analysis and discussion of the data.

$$
\text { Rate }=-d\left[\text { NaTPB } / d t=k\left[T^{2}\right]\left[\text { catalyst }^{n}=k^{\prime}\left[\text { TPB }^{-}\right], \text {where } k^{\prime}=k\left[\text { catalyst }^{n}\right.\right.\right.
$$

\subsection{Phase B Statistical Analysis}

The following summary table lists rate constants for those tests investigating the influence of various organic compounds. Rate constants marked as NRD (i.e., no reaction detected) indicate statistically insignificant changes in NaTPB concentration and limited 3PB and 2PB concentrations. Statistical analysis of the data indicates that a tertiary interaction of the three organic species (i.e., benzene, diphenylmercury, and phenylborate intermediates) promotes the reaction with the suspect active metals. The statistical analysis indicates no primary or secondary effects. In simpler terms, the tests indicate the presence of all three organic groups at the same time accelerates the reaction but no individual group causes an increase in the observed rate. Only tests containing all three resulted in statistically significant rapid reaction rates.

Figure 1 provides further evidence of the tertiary dependence by comparing the [NaTPB] of Tests 56,58 , 59 , and 60 . Test 60 , containing all three organic species, shows the fastest reaction (i.e., greatest loss of NaTPB). Test 58 is the next most reactive system. Test 58 started without adding benzene. The data suggest that the decomposition reaction accelerated after producing benzene from decomposition of a 


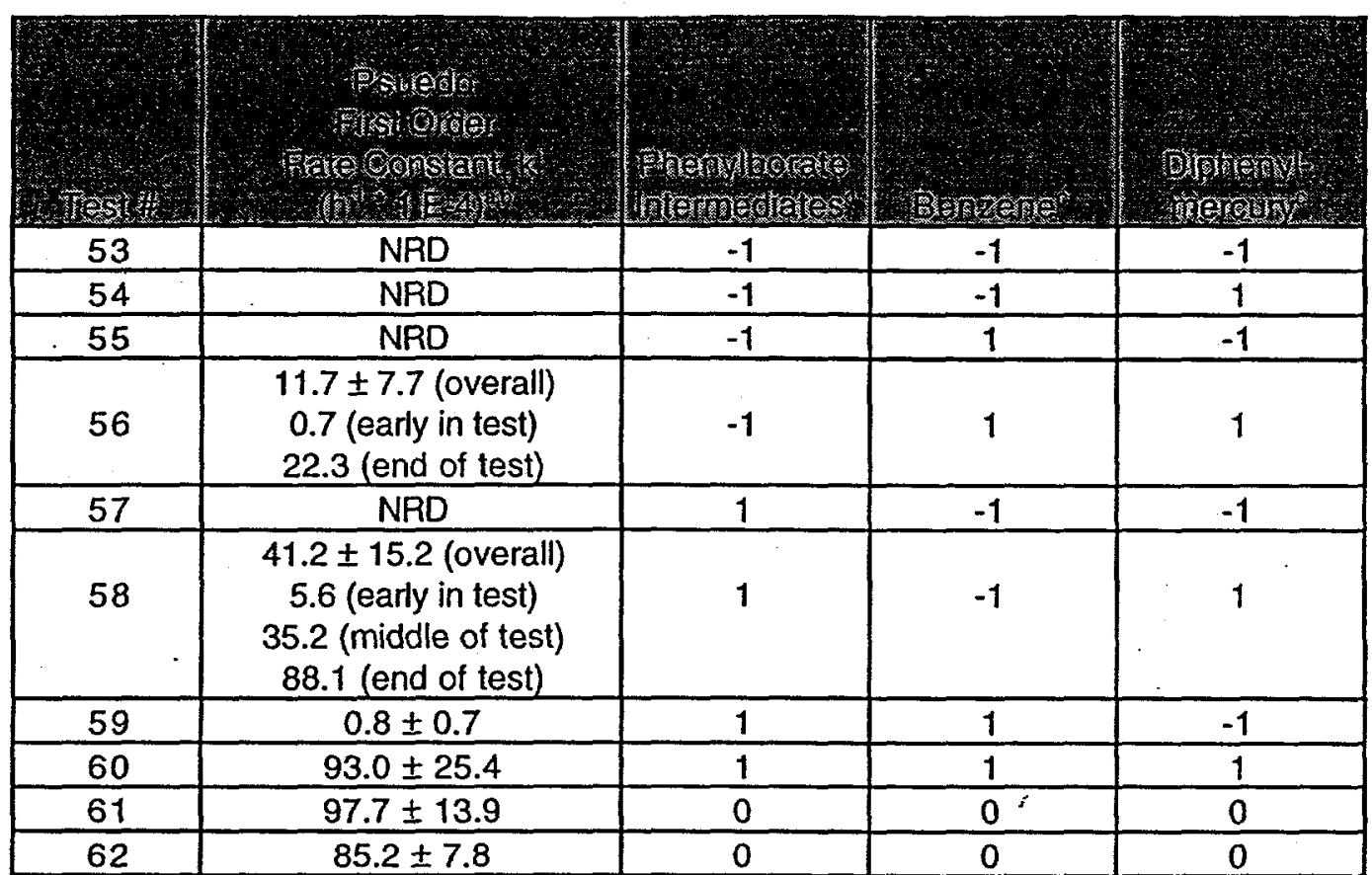

abtained from equation, Rate $=-d\left[\right.$ NaTPB $^{\prime} / \mathrm{dt}=k\left[\right.$ TPB $\left.^{\prime}\right][\text { Catalyst }]^{n}=k^{\prime}\left[\right.$ TPB $\left.^{-}\right]$, where $k^{\prime}=k[\text { Catalyst }]^{n}$

'NRD represents "no reaction detected" and indicates [TPB] data variance not statistically significant at-a $95 \%$ confidence level. $3 \mathrm{~PB}$ and $2 \mathrm{~PB}$ data verifies the lack of reaction.

-1 indicates the group absent from the test, 1 indicates the group present in the test at concentrations listed in Table 1 , and 0 indicates the group present with concentrations one half of those listed in Table 1.

portion of the phenylborate intermediates or copper catalyzed NaTPB decomposition. Rate constants obtained from the three different times during testing (i.e., early, middle, and end) successively increase as shown in the following table. This pattern suggests that increasing benzene concentration speeds the reaction (i.e., reaction not zero order with respect to benzene). However, the data does not allow one to estimate the minimum benzene concentration required to promote reaction although a benzene concentration of $360 \mathrm{mg} / \mathrm{L}$ (i.e., the amount added in Tests 61 and 62 ) does produce near-maximum rate constants.

A similar hypothesis appears valid for Test 56 which lacked phenylborate intermediates at the start of the test. Similarly, the small amount of NaTPB decomposition (due to copper decomposition) might have generated the required organic species and the catalytic reaction began. The limited data does not permit determining the required concentration of intermediates. In terms of order of reaction, one expects that benzene would form in Test 58 faster than phenylborate intermediates in Test 56. Test 58, without added benzene, contains both intermediates and their decomposition catalysts at the onset. Benzene formed from these decompositions from the start of testing at a fairly rapid rate. In Test 56 without added intermediates, decomposition of NaTPB provided the only source of the necessary intermediates. To produce the intermediates, a much slower (relative to the observed rapid NaTPB decomposition) copper catalyzed NaTPB decomposition mechanism occurs. Therefore, Test 58 should start reacting earlier than Test 56. Test 59 cannot produce diphenylmercury in-situ (i.e., no other sources of mercury exist in the tests). Therefore, Test 59 cannot react via a mechanism influenced by mercury compounds. Figure 1 indicates a slow reaction rate for Test 59 suggesting diphenylmercury (or perhaps a form of mercury) participates as a necessary factor for the observed rapid catalytic reaction. Interestingly, a slow but statistically significant reaction $\left(k^{\prime}=(0.8 \pm 0.7) E-4 h^{-1}\right)$ occurred in Test 59. This rate appears consistent with reaction due to copper catalysis. Previous work suggests a rate constant of $1.7 \mathrm{E}-4 \mathrm{~h}^{-1}$ for copper catalysis under these test conditions. [Ref. 9] 
Figure 1. Demonstration of the reactivity of tests containing all three organic species (Test 60) and two of the three organic species (Tests 56,58 , and 59).

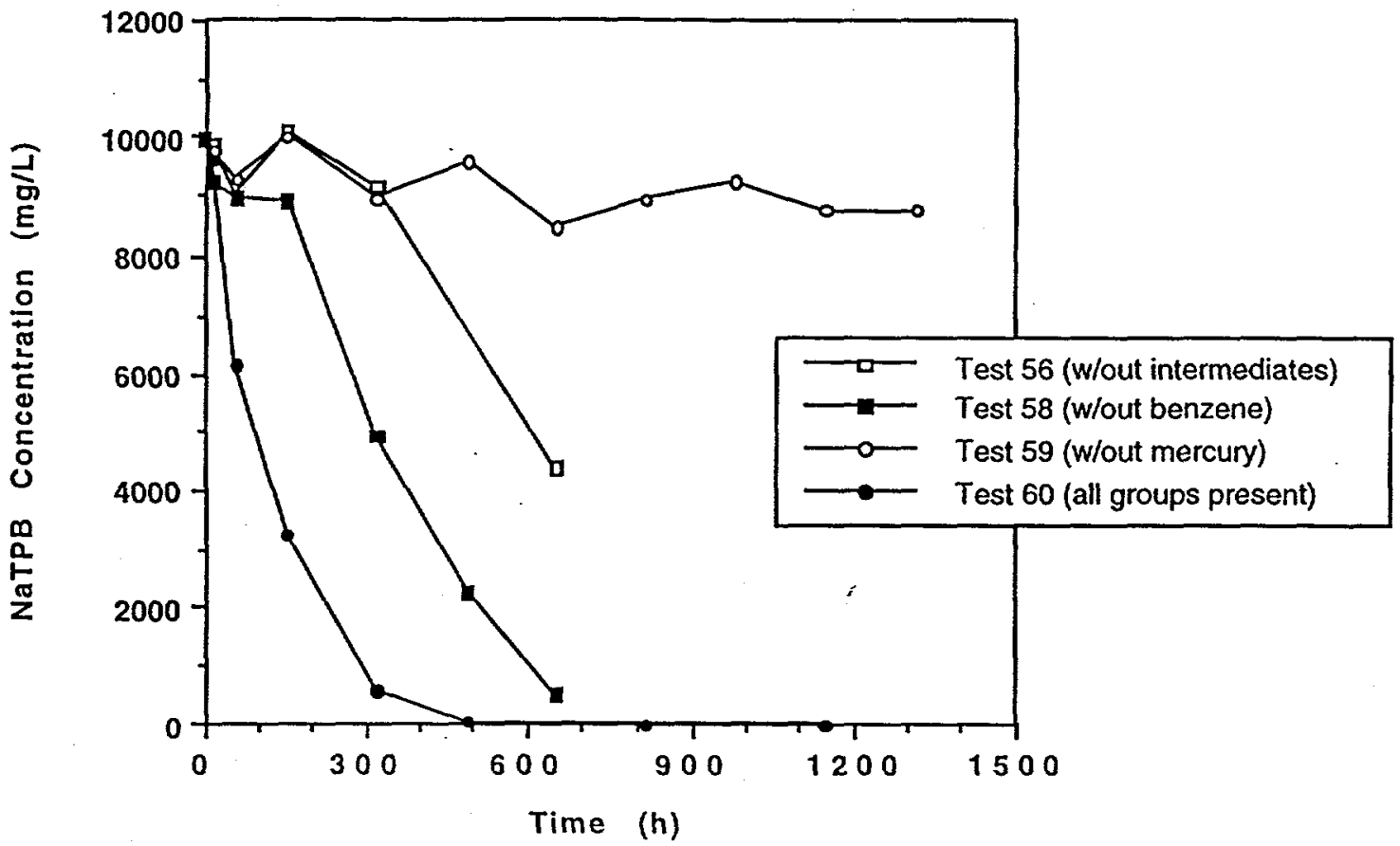

The lack of a rapid reaction (i.e., a $k$ approximately two orders of magnitude greater than observed) in Test 59 differs with data from several other reaction tests without mercury which showed a significant reaction. [Ref. $3,10,11]$ The cause for this discrepancy remains unknown. The author could not identify any single parameter that differed among these tests. Several, but not all, of these tests occurred in larger systems. Difference in physical properties may occur due to changes in scale. For example, the diffusion of benzene or oxygen in the system scales with depth of the solution; larger systems will experience different concentrations of these species. Catalyst preparation also differed among the tests. The tests described in this report used a slightly different simulated sludge from that used in the large scale tests. These laboratory scale tests which exhibited a dependence on mercury used simulated Purex sludge prepared without noble metals (i.e., palladium, ruthenium, rhodium, and silver) or copper. These tests added palladium, ruthenium, rhodium, silver, and copper individually (palladium, ruthenium, hodium, and silver were added from acidic stock solutions). The mercury-free, large scale tests used simulated Purex sludge containing copper and palladium, ruthenium, rhodium, and silver. Analysis of the sludge materials continues as does comparison of the tests to examine the discrepancy.

\subsection{Phase C Statistical Analysis}

The following summary table lists rate constants for those tests investigating the influence of various metals. Rate constants marked as NRD (i.e., no reaction detected) indicate statistically insignificant changes in 3PB and 2PB concentrations. Statistical analysis of the data indicates that palladium exhibits a primary effect on the reaction. The other three metals did not exhibit any effect. The statistical design did not permit identifying secondary or tertiary interactions. Figure 2 clearly shows the influence of palladium. Without palladium, only a very slow or non-detectable reaction proceeds. Similar to Test 59 , a slow reaction occurred in Tests 63 and $65\left(k^{\prime}=(3.2 \pm 2.9) E-4 h^{-1}\right.$ and $(3.1 \pm 2.7) E-4 h^{-1}$, respectively). Again these rates most likely reflect copper catalysis. 


\begin{tabular}{|c|c|c|c|c|c|}
\hline Tesi & 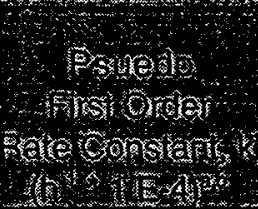 & Argalume & Artreauro\% & Pallatilak & 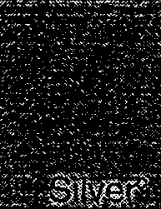 \\
\hline 63 & $3.2 \pm 2.9$ & -1 & -1 & -1 & -1 \\
\hline 64 & $134.6 \pm 29.1$ & -1 & -1 & 1 & 1 \\
\hline 65 & $3.1 \pm 2.7$ & -1 & 1 & -1 & 1 \\
\hline 66 & $105.5 \pm 37.0$ & -1 & 1 & 1 & -1 \\
\hline 67 & NRD & 1 & -1 & -1 & 1 \\
\hline 68 & $131.5 \pm 43.0$ & 1 & -1 & 1 & -1 \\
\hline 69 & NRD & 1 & 1 & -1 & -1 \\
\hline 70 & $98.0 \pm 16.1$ & 1 & 1 & 1 & 1 \\
\hline 71 & $96.6 \pm 30.4$ & 0 & 0 & 0 & 0 \\
\hline 72 & $95.0 \pm 33.8$ & 0 & 0 & 0 & 0 \\
\hline
\end{tabular}

${ }^{\circ}$ Obtained from equation; Rate $=-d\left[\right.$ NaTPB $/ d t=k[T P B][\text { Catalyst }]^{n}=k^{\prime}\left[\right.$ TPB' $\left.^{\prime}\right]$, where $k^{\prime}=k[\text { Catalyst }]^{n}$

"NRD represents "no reaction detected" and indicates [TPB] data variance not statistically significant at a $95 \%$ confidence level. $3 \mathrm{~PB}$ and $2 \mathrm{~PB}$ data verifies the lack of reaction.

${ }^{c}-1$ indicates the group absent from the test, 1 indicates the group present in the test at concentrations listed in Table 1 , and 0 indicates the group present with concentrations one half of those listed in Table 1.

Figure 2. Demonstration of the reactivity of tests containing palladium.

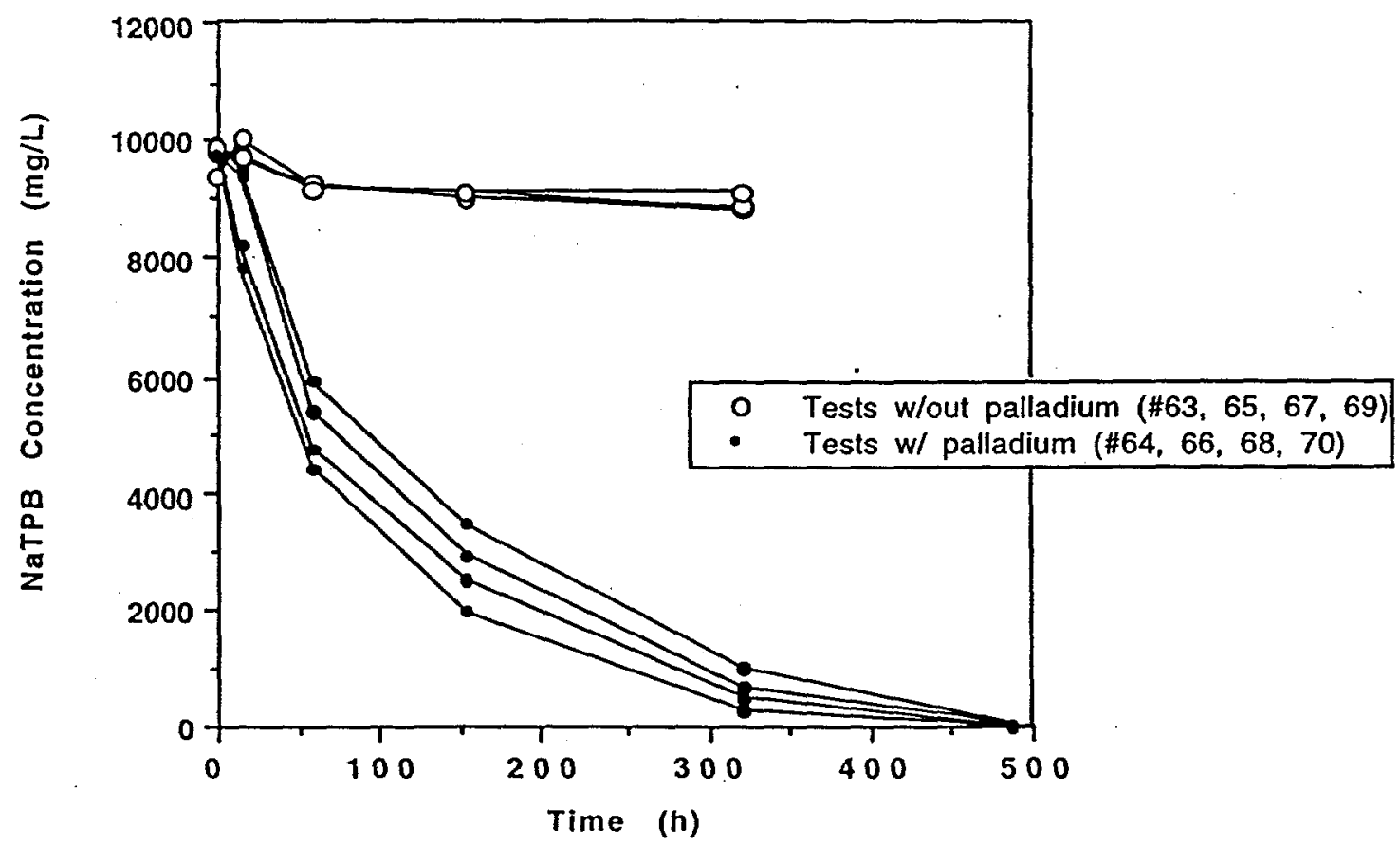




\subsection{Reaction Order}

Testing demonstrated that palladium, benzene, phenylborate intermediates, and diphenylmercury play integral parts in the catalytic system for the observed rapid decomposition of NaTPB. The author further analyzed Phase $B$ and Phase $C$ data to determine the reaction order of each reactant. The limited amount of data for tests with varying concentrations of each component prevents determining the reaction order with high certainty. The data indicate a reaction order for palladium of less than unity. The reaction appears zero order with respect to the three organic groups. However, the increasing rate constant observed for Test 58 indicates a non-zero reaction order with respect to benzene. The table below presents the molar ratio (relative to palladium) of each of the components at their respective ECC concentration. Given the large molar ratio for the organic species, one would not expect to discern the reaction order with such a limited data set.

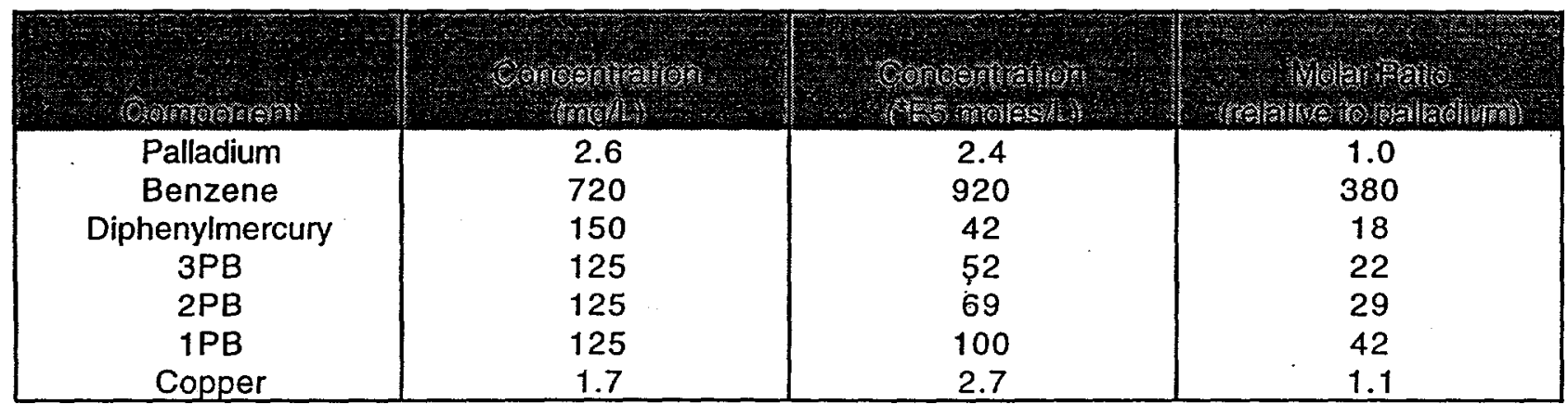

\subsection{Conclusions}

The second and third sets, Phases $B$ and $C$, of statistical design catalyst identification tests are complete. Phase $\mathrm{B}$ testing determined the presence of all three organic species (i.e.; benzene, diphenylmercury, and phenylborate intermediates) as necessary to facilitate the observed rapid decomposition. Removal of any one of the three species either delays or prevents reaction. Phase $\mathrm{C}$ testing identified palladium as the influential metal in catalyzing the decomposition at the high rates of these experiments. (Copper, in comparable concentrations at these condition, only contributes to $-1 \%$ of the measured reaction rates.) The limited number of centerpoint tests indicate a reaction order of less than unity with respect to palladium. The reaction appears zero order with respect to the organics; however, their large molar ratio (with respect to palladium) prevents determining this dependency with any certainty from these tests.

\subsection{Path Forward}

The final set (i.e., Phase D) of these statistically designed tests investigates the potential catalytic activity of two conditions or chemicals omitted from all previous catalyst identification testing. These experiments will examine the effect of radiolysis and the potential catalytic effect of uranium under conditions similar to those discussed in this document. Additionally, further work may prove necessary to understand the discrepancies observed with respect to diphenylmercury. 


\subsection{Tables}

Table 1. Enhanced Comprehensive Catalyst components for Phase B and C statistical design catalyst identification tests with target concentrations provided in parentheses.

Inactive Components

methanol ( $5 \mathrm{mg} / \mathrm{L})$

isopropanol $(50 \mathrm{mg} / \mathrm{L})$

phenol (125 $\mathrm{mg} / \mathrm{L})$

biphenyl (150 mg/L)

copper $(1.7 \mathrm{mg} / \mathrm{L})$

cadmium (0.4 mg/L)

molybdenum (12 mg/L)

cerium ( $0.3 \mathrm{mg} / \mathrm{L})$

silicon (16 mg/L)

selenium (1 $\mathrm{mg} / \mathrm{L})$

arsenic (0.04 mg/L)

tin $(2.1 \mathrm{mg} / \mathrm{L})$

cobalt $(0.04 \mathrm{mg} / \mathrm{L})$

calcium (12.2 mg/L)

strontium $(0.1 \mathrm{mg} / \mathrm{L})$

lanthanum $(0.05 \mathrm{mg} / \mathrm{L})$

iron $(579 \mathrm{mg} / \mathrm{L})$

chromium (64 mg/L)

zinc (12.8 $\mathrm{mg} / \mathrm{L})$

manganese $(118 \mathrm{mg} / \mathrm{L})$

nickel (50 mg/L)

aluminum $(96 \mathrm{mg} / \mathrm{L})$

magnesium ( $2 \mathrm{mg} / \mathrm{L}$ )

zirconium (50 mg/L)

lead (6 mg/L)

monosodium titanate $(2 \mathrm{~g} / \mathrm{L})$

\section{Suspect Active Organics}

benzene $(720 \mathrm{mg} / \mathrm{L})$

diphenylmercury $(150 \mathrm{mg} / \mathrm{L})$

Phenylborate intermediates

- 3PB (125 mg/L)

- 2PB (125 mg/L)

- 1PB (125 mg/L)

Suspect Active Metals

ruthenium $(5.4 \mathrm{mg} / \mathrm{L})$

rhodium (1.4 $\mathrm{mg} / \mathrm{L}$ )

palladium $(2.6 \mathrm{mg} / \mathrm{L})$

silver $(6.8 \mathrm{mg} / \mathrm{L})$ 
Table 2: Phase B statistical design for suspect active organics identification testing.

\begin{tabular}{|c|c|c|c|}
\hline Test \# & $\begin{array}{c}\text { Phenylborate } \\
\text { Intermediates }\end{array}$ & Benzene $^{\mathrm{a}}$ & $\begin{array}{c}\text { Diphenyl- } \\
\text { mercury }^{\mathrm{a}}\end{array}$ \\
\hline 53 & -1 & -1 & -1 \\
\hline 54 & -1 & -1 & 1 \\
\hline 55 & -1 & 1 & -1 \\
\hline 56 & -1 & 1 & 1 \\
\hline 57 & 1 & -1 & -1 \\
\hline 58 & 1 & -1 & 1 \\
\hline 59 & 1 & 1 & -1 \\
\hline 60 & 1 & 1 & 1 \\
\hline 61 & 0 & 0 & 0 \\
\hline 62 & 0 & 0 & 0 \\
\hline
\end{tabular}

-1 indicates the group absent from the test. 1 indicates the group present with concentrations listed in Table 1. 0 indicates the group present with concentrations one half of those listed in Table 1.

Table 3: Phase $\mathrm{C}$ statistical design for suspect active metals identification testing.

\begin{tabular}{|c|c|c|c|c|}
\hline Test \# & Rhodium $^{\mathrm{a}}$ & Ruthenium $^{\mathrm{a}}$ & Palladium $^{\mathrm{a}}$ & Silver $^{\mathrm{a}}$ \\
\hline 63 & -1 & -1 & -1 & -1 \\
\hline 64 & -1 & -1 & 1 & 1 \\
\hline 65 & -1 & 1 & -1 & 1 \\
\hline 66 & -1 & 1 & 1 & -1 \\
\hline 67 & 1 & -1 & -1 & 1 \\
\hline 68 & 1 & -1 & 1 & -1 \\
\hline 69 & 1 & 1 & -1 & -1 \\
\hline 70 & 1 & 1 & 1 & 1 \\
\hline 71 & 0 & 0 & 0 & 0 \\
\hline 72 & 0 & 0 & 0 & 0 \\
\hline
\end{tabular}

a -1 indicates the group absent from the test. 1 indicates the group present with concentrations listed in Table 1. 0 indicates the group present with concentrations one half of those listed in Table 1. 
Table 4. Standard tetraphenylborate slurry simulant for Phase A statistical design catalyst identification tests (target concentrations).

\begin{tabular}{|c|c|}
\hline & $\begin{array}{c}2.7 \mathrm{M} \mathrm{Na}^{+} \\
\text {Slurry } \\
\text { Concentration }\end{array}$ \\
\hline Component & $2.66 \mathrm{M}$ \\
\hline sodium & $1.49 \mathrm{M}$ \\
\hline hydroxide & $0.39 \mathrm{M}$ \\
\hline nitrite & $0.38 \mathrm{M}$ \\
\hline nitrate & $0.09 \mathrm{M}$ \\
\hline aluminate & $0.006 \mathrm{M}$ \\
\hline sulfate & $0.10 \mathrm{M}$ \\
\hline carbonate & $0.008 \mathrm{M}$ \\
\hline chloride & $0.004 \mathrm{M}$ \\
\hline fluoride & $0.003 \mathrm{M}$ \\
\hline phosphate & $0.02 \mathrm{M}$ \\
\hline TPB (b) $^{\mathrm{b}}$ & $0 \mathrm{~g} / \mathrm{L}$ \\
\hline NaTPB (insoluble) & \\
\hline KTPB (insoluble) & $48 \mathrm{~g} / \mathrm{L}$ \\
\hline
\end{tabular}

aTheoretical (determined by filtrate density). [Ref. 11]

'Theoretical (determined by sodium ion concentration). [Ref. 12]

${ }^{\circ}$ Concentration represents $\sim 4$ wt \% KTPB. 
Table 5. Soluble sodium tetraphenylborate, triphenylborane (3PB) and diphenylborinic acid (2PB) concentrations versus time for Test 53 .

\begin{tabular}{|c|c|c|c|}
\hline $\begin{array}{c}\text { Reaction } \\
\text { Time }(\mathrm{h})\end{array}$ & $\begin{array}{c}\text { Soluble NaTPB } \\
(\mathrm{mg} / \mathrm{L})\end{array}$ & $\begin{array}{c}3 \mathrm{SPB} \\
(\mathrm{mg} / \mathrm{L})\end{array}$ & $\begin{array}{c}2 \mathrm{~PB} \\
(\mathrm{mg} / \mathrm{L})\end{array}$ \\
\hline 0.0 & 10054 & $<10$ & $<10$ \\
\hline 15.2 & 9318 & $<10$ & $<10$ \\
\hline 59.1 & 8767 & $<10$ & $<10$ \\
\hline 153 & 9415 & $<10$ & $<10$ \\
\hline 321 & 8380 & $<10$ & $<10$ \\
\hline
\end{tabular}

Table 6. Soluble sodium tetraphenylborate, triphenylborane (3PB) and diphenylborinic acid (2PB) concentrations versus time for Test 54 .

\begin{tabular}{|c|c|c|c|}
\hline $\begin{array}{c}\text { Reaction } \\
\text { Time (h) }\end{array}$ & $\begin{array}{c}\text { Soluble NaTPB } \\
(\mathrm{mg} / \mathrm{L})\end{array}$ & $\begin{array}{c}3 \mathrm{~PB} \\
(\mathrm{mg} / \mathrm{L})\end{array}$ & $\begin{array}{c}2 \mathrm{~PB} \\
(\mathrm{mg} / \mathrm{L})\end{array}$ \\
\hline 0.0 & 9866 & $<10$ & $<10$ \\
\hline 15.2 & 9654 & $<10$ & $<10$ \\
\hline 59.1 & 8944 & $<10$ & $<10$ \\
\hline 153 & 9585 & $<10$ & $<10$ \\
\hline 321 & 8860 & $<10$ & $<10$ \\
\hline
\end{tabular}

Table 7. Soluble sodium tetraphenylborate, triphenylborane (3PB) and diphenylborinic acid (2PB) concentrations versus time for Test 55.

\begin{tabular}{|c|c|c|c|}
\hline $\begin{array}{c}\text { Reaction } \\
\text { Time (h) }\end{array}$ & $\begin{array}{c}\text { Soluble NaTPB } \\
\text { (mg/L) }\end{array}$ & $\begin{array}{c}\text { 3PB } \\
(\mathrm{mg} / \mathrm{L})\end{array}$ & $\begin{array}{c}2 \mathrm{~PB} \\
(\mathrm{mg} / \mathrm{L})\end{array}$ \\
\hline 0.0 & 10006 & $<10$ & $<10$ \\
\hline 15.2 & 9823 & $<10$ & $<10$ \\
\hline 59.1 & 8548 & $<10$ & $<10$ \\
\hline 153 & 9978 & $<10$ & $<10$ \\
\hline 321 & 8777 & $<10$ & $<10$ \\
\hline
\end{tabular}

Table 8. Soluble sodium tetraphenylborate, triphenylborane (3PB) and diphenylborinic acid (2PB) concentrations versus time for Test 56.

\begin{tabular}{|c|c|c|c|}
\hline $\begin{array}{c}\text { Reaction } \\
\text { Time }(\mathrm{h})\end{array}$ & $\begin{array}{c}\text { Soluble NaTPB } \\
(\mathrm{mg} / \mathrm{L})\end{array}$ & $\begin{array}{c}3 \mathrm{~PB} \\
(\mathrm{mg} / \mathrm{L})\end{array}$ & $\begin{array}{c}2 \mathrm{~PB} \\
(\mathrm{mg} / \mathrm{L})\end{array}$ \\
\hline 0.0 & 10033 & $<10$ & $<10$ \\
\hline 15.2 & 9863 & $<10$ & $<10$ \\
\hline 59.1 & 9021 & $<10$ & $<10$ \\
\hline 153 & 10099 & 16 & $<10$ \\
\hline 321 & 9165 & 31 & $<10$ \\
\hline 650 & 4389 & 1871 & 744 \\
\hline
\end{tabular}


Table 9. Soluble sodium tetraphenylborate, triphenylborane (3PB) and diphenylborinic acid (2PB) concentrations versus time for Test 57.

\begin{tabular}{|c|c|c|c|}
\hline $\begin{array}{c}\text { Reaction } \\
\text { Time (h) }\end{array}$ & $\begin{array}{c}\text { Soluble NaTPB } \\
\text { (mg/L) }\end{array}$ & $\begin{array}{c}\text { 3PB } \\
(\mathrm{mg} / \mathrm{L})\end{array}$ & $\begin{array}{c}\text { 2PB } \\
(\mathrm{mg} / \mathrm{L})\end{array}$ \\
\hline 0.0 & 9884 & 86 & 125 \\
\hline 15.2 & 9306 & 86 & 122 \\
\hline 59.1 & 8727 & 69 & 69 \\
\hline 153 & 9385 & 84 & 36 \\
\hline 321 & 8424 & 76 & $<10$ \\
\hline
\end{tabular}

Table 10. Soluble sodium tetraphenylborate, triphenylborane (3PB) and diphenylborinic acid (2PB) concentrations versus time for Test 58.

\begin{tabular}{|c|c|c|c|}
\hline $\begin{array}{c}\text { Reaction } \\
\text { Time }(\mathrm{h})\end{array}$ & $\begin{array}{c}\text { Soluble NaTPB } \\
(\mathrm{mg} / \mathrm{L})\end{array}$ & $\begin{array}{c}3 \mathrm{~PB} \\
(\mathrm{mg} / \mathrm{L})\end{array}$ & $\begin{array}{c}2 \mathrm{~PB} \\
(\mathrm{mg} / \mathrm{L})\end{array}$ \\
\hline 0.0 & 9956 & 87 & 156 \\
\hline 15.2 & 9260 & 82 & 130 \\
\hline 59.1 & 8983 & 91 & 78 \\
\hline 153 & 8902 & 545 & 75 \\
\hline 321 & 4927 & 2377 & 367 \\
\hline 486 & 2247 & 2880 & 845 \\
\hline 650 & 527 & 2357 & 1071 \\
\hline
\end{tabular}

Table 11. Soluble sodium tetraphenylborate, triphenylborane (3PB) and diphenylborinic acid (2PB) concentrations versus time for Test 59.

\begin{tabular}{|c|c|c|c|}
\hline $\begin{array}{c}\text { Reaction } \\
\text { Time }(\mathrm{h})\end{array}$ & $\begin{array}{c}\text { Soluble NaTPB } \\
(\mathrm{mg} / \mathrm{L})\end{array}$ & $\begin{array}{c}\text { 3PB } \\
(\mathrm{mg} / \mathrm{L})\end{array}$ & $\begin{array}{c}2 \mathrm{~PB} \\
(\mathrm{mg} / \mathrm{L})\end{array}$ \\
\hline 0.0 & 10003 & 86 & 157 \\
\hline 15.2 & 9769 & 83 & 118 \\
\hline 59.1 & 9320 & 80 & 62 \\
\hline 153 & 10010 & 86 & 39 \\
\hline 321 & 8976 & 80 & $<10$ \\
\hline 486 & 9578 & 88 & $<10$ \\
\hline 650 & 8490 & 84 & $<10$ \\
\hline 817 & 8960 & 78 & $<10$ \\
\hline 982 & 9243 & 57 & 5 \\
\hline 1149 & 8751 & 54 & $<10$ \\
\hline 1317 & 8774 & 69 & $<10$ \\
\hline
\end{tabular}


Table 12. Soluble sodium tetraphenylborate, triphenylborane (3PB), diphenylborinic acid (2PB), and potassium concentrations versus time for Test 60 .

\begin{tabular}{|c|c|c|c|c|}
\hline $\begin{array}{c}\text { Reaction } \\
\text { Time (h) }\end{array}$ & $\begin{array}{c}\text { Soluble NaTPB } \\
(\mathrm{mg} / \mathrm{L})\end{array}$ & $\begin{array}{c}3 \mathrm{~PB} \\
(\mathrm{mg} / \mathrm{L})\end{array}$ & $\begin{array}{c}2 \mathrm{~PB} \\
(\mathrm{mg} / \mathrm{L})\end{array}$ & $\begin{array}{c}\text { Soluble } \\
\text { Potassium } \\
(\mathrm{mg} / \mathrm{L})^{\mathrm{a}}\end{array}$ \\
\hline 0.0 & 9976 & 87 & 116 & $\mathrm{NA}$ \\
\hline 15.2 & 9635 & 256 & 139 & $\mathrm{NA}$ \\
\hline 59.1 & 6125 & 2047 & 481 & $\mathrm{NA}$ \\
\hline 153 & 3252 & 3165 & 1679 & $\mathrm{NA}$ \\
\hline 321 & 577 & 2323 & 2217 & $\mathrm{NA}$ \\
\hline 486 & 26 & 1107 & 1885 & 3.445 \\
\hline 817 & 10 & 66 & 322 & 40.300 \\
\hline 1149 & $<10$ & 5 & 81 & 79.850 \\
\hline
\end{tabular}

${ }^{2} \mathrm{NA}$ indicates no analysis performed.

Table 13. Soluble sodium tetraphenylborate, triphenylborane (3PB), diphenylborinic acid (2PB), and potassium concentrations versus time for Test 61.

\begin{tabular}{|c|c|c|c|c|}
\hline $\begin{array}{c}\text { Reaction } \\
\text { Time }(\mathrm{h})\end{array}$ & $\begin{array}{c}\text { Soluble NaTPB } \\
(\mathrm{mg} / \mathrm{L})\end{array}$ & $\begin{array}{c}3 P B \\
(\mathrm{mg} / \mathrm{L})\end{array}$ & $\begin{array}{c}2 \mathrm{2PB} \\
(\mathrm{mg} / \mathrm{L})\end{array}$ & $\begin{array}{c}\text { Soluble } \\
\text { Potassium } \\
(\mathrm{mg} / \mathrm{L})^{\mathrm{a}}\end{array}$ \\
\hline 0.0 & 9694 & 42 & 44 & $\mathrm{NA}$ \\
\hline 15.2 & 9588 & 59 & 61 & $\mathrm{NA}$ \\
\hline 59.1 & 7431 & 1224 & 297 & $\mathrm{NA}$ \\
\hline 153 & 3848 & 2783 & 1524 & $\mathrm{NA}$ \\
\hline 321 & 749 & 1989 & 1550 & $\mathrm{NA}$ \\
\hline 486 & 54 & 1034 & 1065 & $<0.160$ \\
\hline 817 & 5 & 66 & 202 & 33.020 \\
\hline 1149 & $<10$ & 7 & 52 & 52.950 \\
\hline
\end{tabular}

aNA indicates no analysis performed.

Table 14. Soluble sodium tetraphenylborate, triphenylborane (3PB) and diphenylborinic acid (2PB) concentrations versus time for Test 62 .

\begin{tabular}{|c|c|c|c|}
\hline $\begin{array}{c}\text { Reaction } \\
\text { Time (h) }\end{array}$ & $\begin{array}{c}\text { Soluble NaTPB } \\
(\mathrm{mg} / \mathrm{L})\end{array}$ & $\begin{array}{c}3 \mathrm{~PB} \\
(\mathrm{mg} / \mathrm{L})\end{array}$ & $\begin{array}{c}2 \mathrm{~PB} \\
(\mathrm{mg} / \mathrm{L})\end{array}$ \\
\hline 0.0 & 9965 & 44 & 79 \\
\hline 15.2 & 9760 & 85 & 70 \\
\hline 59.1 & 6120 & 1751 & 538 \\
\hline 153 & 3336 & 2670 & 1728 \\
\hline 321 & 806 & 2272 & 1350 \\
\hline 486 & 154 & 1464 & 1500 \\
\hline
\end{tabular}


Table 15. Soluble sodium tetraphenylborate, triphenylborane (3PB) and diphenylborinic acid (2PB) concentrations versus time for Test 63.

\begin{tabular}{|c|c|c|c|}
\hline $\begin{array}{c}\text { Reaction } \\
\text { Time }(\mathrm{h})\end{array}$ & $\begin{array}{c}\text { Soluble NaTPB } \\
(\mathrm{mg} / \mathrm{L})\end{array}$ & $\begin{array}{c}3 \mathrm{~PB} \\
(\mathrm{mg} / \mathrm{L})\end{array}$ & $\begin{array}{c}2 \mathrm{~PB} \\
(\mathrm{mg} / \mathrm{L})\end{array}$ \\
\hline 0.0 & 9846 & 86 & 151 \\
\hline 15.2 & 9735 & 80 & 118 \\
\hline 59.1 & 9190 & 95 & 68 \\
\hline 153 & 9095 & 96 & 43 \\
\hline 321 & 8800 & 75 & $<10$ \\
\hline
\end{tabular}

Table 16. Soluble sodium tetraphenylborate, triphenylborane (3PB), diphenylborinic acid (2PB), and potassium concentrations versus time for Test 64.

\begin{tabular}{|c|c|c|c|c|}
\hline $\begin{array}{c}\text { Reaction } \\
\text { Time }(\mathrm{h})\end{array}$ & $\begin{array}{c}\text { Soluble NaTPB } \\
(\mathrm{mg} / \mathrm{L})\end{array}$ & $\begin{array}{c}3 \mathrm{~PB} \\
(\mathrm{mg} / \mathrm{L})\end{array}$ & $\begin{array}{c}2 \mathrm{~PB} \\
(\mathrm{mg} / \mathrm{L})\end{array}$ & $\begin{array}{c}\text { Soluble } \\
\text { Potassium } \\
(\mathrm{mg} / \mathrm{L})^{\mathrm{a}}\end{array}$ \\
\hline 0.0 & 9903 & 77 & 153 & NA \\
\hline 15.2 & 7828 & 1037 & 449 & NA \\
\hline 59.1 & 4440 & 2265 & 1038 & NA \\
\hline 153 & 1994 & 2594 & 1516 & NA \\
\hline 321 & 287 & 1845 & 1811 & $\mathrm{NA}$ \\
\hline 486 & $<10$ & 587 & 1293 & 12.920 \\
\hline 817 & $<10$ & 38 & 248 & 43.940 \\
\hline 1149 & $<10$ & 4 & 78 & 76.550 \\
\hline
\end{tabular}

${ }^{a} \mathrm{NA}$ indicates no analysis performed.

Table 17. Soluble sodium tetraphenylborate, triphenylborane (3PB) and diphenylborinic acid (2PB) concentrations versus time for Test 65.

\begin{tabular}{|c|c|c|c|}
\hline $\begin{array}{c}\text { Reaction } \\
\text { Time }(\mathrm{h})\end{array}$ & $\begin{array}{c}\text { Soluble NaTPB } \\
(\mathrm{mg} / \mathrm{L})\end{array}$ & $\begin{array}{c}3 \mathrm{~PB} \\
(\mathrm{mg} / \mathrm{L})\end{array}$ & $\begin{array}{c}2 \mathrm{~PB} \\
(\mathrm{mg} / \mathrm{L})\end{array}$ \\
\hline 0.0 & 9801 & 84 & 153 \\
\hline 15.2 & 9692 & 80 & 116 \\
\hline 59.1 & 9235 & 79 & 84 \\
\hline 153 & 9011 & 102 & 24 \\
\hline 321 & 8828 & 77 & $<10$ \\
\hline
\end{tabular}

Table 18. Soluble sodium tetraphenylborate, triphenylborane (3PB) and diphenylborinic acid (2PB) concentrations versus time for Test 66.

\begin{tabular}{|c|c|c|c|}
\hline $\begin{array}{c}\text { Reaction } \\
\text { Time }(\mathrm{h})\end{array}$ & $\begin{array}{c}\text { Soluble NaTPB } \\
(\mathrm{mg} / \mathrm{L})\end{array}$ & $\begin{array}{c}3 \mathrm{~PB} \\
(\mathrm{mg} / \mathrm{L})\end{array}$ & $\begin{array}{c}2 \mathrm{~PB} \\
(\mathrm{mg} / \mathrm{L})\end{array}$ \\
\hline 0.0 & 9991 & 84 & 158 \\
\hline 15.2 & 9522 & 195 & 140 \\
\hline 59.1 & 5927 & 1773 & 714 \\
\hline 153 & 3461 & 2475 & 1246 \\
\hline 321 & 1019 & 1861 & 1402 \\
\hline 486 & 40 & 733 & 1401 \\
\hline
\end{tabular}


Table 19. Soluble sodium tetraphenylborate, triphenylborane (3PB) and diphenylborinic acid (2PB) concentrations versus time for Test 67.

\begin{tabular}{|c|c|c|c|}
\hline $\begin{array}{c}\text { Reaction } \\
\text { Time }(\mathrm{h})\end{array}$ & $\begin{array}{c}\text { Soluble NaTPB } \\
(\mathrm{mg} / \mathrm{L})\end{array}$ & $\begin{array}{c}3 \mathrm{~PB} \\
(\mathrm{mg} / \mathrm{L})\end{array}$ & $\begin{array}{c}2 \mathrm{~PB} \\
(\mathrm{mg} / \mathrm{L})\end{array}$ \\
\hline 0.0 & 9355 & 79 & 148 \\
\hline 15.2 & 10043 & 90 & 121 \\
\hline 59.1 & 9238 & 78 & 60 \\
\hline 153 & 9036 & 79 & 25 \\
\hline 321 & 8860 & 74 & $<10$ \\
\hline
\end{tabular}

Table 20. Soluble sodium tetraphenylborate, triphenylborane (3PB), diphenylborinic acid (2PB), and potassium concentrations versus time for Test 68.

\begin{tabular}{|c|c|c|c|c|}
\hline $\begin{array}{c}\text { Reaction } \\
\text { Time }(\mathrm{h})\end{array}$ & $\begin{array}{c}\text { Soluble NaTPB } \\
(\mathrm{mg} / \mathrm{L})\end{array}$ & $\begin{array}{c}3 \mathrm{~PB} \\
(\mathrm{mg} / \mathrm{L})\end{array}$ & $\begin{array}{c}2 \mathrm{~PB} \\
(\mathrm{mg} / \mathrm{L})\end{array}$ & $\begin{array}{c}\text { Soluble } \\
\text { Potassium } \\
(\mathrm{mg} / \mathrm{L})^{\mathbf{a}}\end{array}$ \\
\hline 0.0 & 9930 & 88 & 158 & $\mathrm{NA}$ \\
\hline 15.2 & 8208 & 904 & 458 & $\mathrm{NA}$ \\
\hline 59.1 & 4790 & 2173 & 1045 & $\mathrm{NA}$ \\
\hline 153 & 2495 & 2150 & 1573 & $\mathrm{NA}$ \\
\hline 321 & 490 & 1430 & 1541 & $\mathrm{NA}$ \\
\hline 486 & $<10$ & 476 & 1135 & 21.420 \\
\hline 817 & $<10$ & 16 & 187 & 95.030 \\
\hline 1149 & $<10$ & $<10$ & 59 & 170.750 \\
\hline
\end{tabular}

${ }^{a} \mathrm{NA}$ indicates no analysis performed.

Table 21. Soluble sodium tetraphenylborate, triphenylborane (3PB) and diphenylborinic acid (2PB) concentrations versus time for Test 69.

\begin{tabular}{|c|c|c|c|}
\hline $\begin{array}{c}\text { Reaction } \\
\text { Time }(\mathrm{h})\end{array}$ & $\begin{array}{c}\text { Soluble NaTPB } \\
(\mathrm{mg} / \mathrm{L})\end{array}$ & $\begin{array}{c}3 \mathrm{~PB} \\
(\mathrm{mg} / \mathrm{L})\end{array}$ & $\begin{array}{c}2 \mathrm{~PB} \\
(\mathrm{mg} / \mathrm{L})\end{array}$ \\
\hline 0.0 & 9885 & 82 & 152 \\
\hline 15.2 & 9692 & 80 & 116 \\
\hline 59.1 & 9161 & 95 & 65 \\
\hline 153 & 9104 & 77 & 34 \\
\hline 321 & 9131 & 75 & $<10$ \\
\hline
\end{tabular}

Table 22. Soluble sodium tetraphenylborate, triphenylborane (3PB) and diphenylborinic acid (2PB) concentrations versus time for Test 70 .

\begin{tabular}{|c|c|c|c|}
\hline $\begin{array}{c}\text { Reaction } \\
\text { Time }(\mathrm{h})\end{array}$ & $\begin{array}{c}\text { Soluble NaTPB } \\
(\mathrm{mg} / \mathrm{L})\end{array}$ & $\begin{array}{c}3 \mathrm{~PB} \\
(\mathrm{mg} / \mathrm{L})\end{array}$ & $\begin{array}{c}\text { 2PB } \\
(\mathrm{mg} / \mathrm{L})\end{array}$ \\
\hline 0.0 & 9738 & 82 & 155 \\
\hline 15.2 & 9410 & 284 & 144 \\
\hline 59.1 & 5385 & 2196 & 674 \\
\hline 153 & 2944 & 2572 & 1193 \\
\hline 321 & 667 & 2174 & 1670 \\
\hline 486 & 72 & 1233 & 1516 \\
\hline
\end{tabular}


Table 23. Soluble sodium tetraphenylborate, triphenylborane (3PB) and diphenylborinic acid (2PB) concentrations versus time for Test 71.

\begin{tabular}{|c|c|c|c|}
\hline $\begin{array}{c}\text { Reaction } \\
\text { Time }(\mathrm{h})\end{array}$ & $\begin{array}{c}\text { Soluble NaTPB } \\
(\mathrm{mg} / \mathrm{L})\end{array}$ & $\begin{array}{c}3 \mathrm{~PB} \\
(\mathrm{mg} / \mathrm{L})\end{array}$ & $\begin{array}{c}2 \mathrm{~PB} \\
(\mathrm{mg} / \mathrm{L})\end{array}$ \\
\hline 0.0 & 9743 & 95 & 141 \\
\hline 15.2 & 9705 & 108 & 122 \\
\hline 59.1 & 7830 & 908 & 177 \\
\hline 153 & 4468 & 2463 & 711 \\
\hline 321 & 1500 & 2383 & 1300 \\
\hline 486 & 308 & 1742 & 1690 \\
\hline 650 & $<10$ & 545 & 1044 \\
\hline
\end{tabular}

Table 24. Soluble sodium tetraphenylborate, triphenylborane (3PB) and diphenylborinic acid (2PB) concentrations versus time for Test 72 .

\begin{tabular}{|c|c|c|c|}
\hline $\begin{array}{c}\text { Reaction } \\
\text { Time }(\mathrm{h})\end{array}$ & $\begin{array}{c}\text { Soluble NaTPB } \\
(\mathrm{mg} / \mathrm{L})\end{array}$ & $\begin{array}{c}\text { 3PB } \\
(\mathrm{mg} / \mathrm{L})\end{array}$ & $\begin{array}{c}\text { 2PB } \\
(\mathrm{mg} / \mathrm{L})\end{array}$ \\
\hline 0.0 & 10294 & 87 & 162 \\
\hline 15.2 & 9594 & 120 & 123 \\
\hline 59.1 & 7503 & 1283 & 227 \\
\hline 153 & 4713 & 2485 & 675 \\
\hline 321 & 1684 & 2787 & 1796 \\
\hline 486 & 394 & 2023 & 2128 \\
\hline 650 & $<10$ & 916 & 1811 \\
\hline
\end{tabular}


Table 25. Kinetics data for Phase B and C statistical design catalyst identification Tests 53 through 72.

\begin{tabular}{|c|c|c|}
\hline Test & $\begin{array}{c}\text { Pseudo first } \\
\text { Order Rate } \\
\text { Constant } \mathrm{k}^{3} \\
\left(\mathrm{~h}^{-1} \star^{\mathrm{E}} \mathrm{-4}\right)\end{array}$ & Comments \\
\hline 53 & $3.9 \pm 6.6$ & no reaction detected \\
\hline 54 & $2.4 \pm 5.1$ & no reaction detected \\
\hline 55 & $2.6 \pm 9.4$ & no reaction detected \\
\hline 56 & $11.7 \pm 7.7$ & no reaction detected \\
\hline 57 & $3.4 \pm 6.1$ & \\
\hline 58 & $41.2 \pm 15.2$ & \\
\hline 59 & $0.8 \pm 0.7$ & \\
\hline 60 & $93.0 \pm 25.4$ & \\
\hline 61 & $97.7 \pm 13.9$ & \\
\hline 62 & $85.2 \pm 7.8$ & \\
\hline 63 & $3.2 \pm 2.9$ & \\
\hline 64 & $134.6 \pm 29.1$ & no reaction detected \\
\hline 65 & $3.1 \pm 2.7$ & \\
\hline 66 & $105.5 \pm 37.0$ & no reaction detected \\
\hline 67 & $2.7 \pm 4.4$ & \\
\hline 68 & $131.5 \pm 43.0$ & \\
\hline 69 & $2.1 \pm 3.8$ & \\
\hline 70 & $98.0 \pm 16.1$ & \\
\hline 71 & $96.6 \pm 30.4$ & \\
\hline 72 & $95.0 \pm 33.8$ & \\
\hline
\end{tabular}

${ }^{\mathrm{a}}$ Obtained from equation, Rate $=-\mathrm{d}[\mathrm{NaTPB}] / \mathrm{dt}=\mathrm{k}[\mathrm{TPB}][\text { Catalyst }]^{n}=\mathrm{k}^{\prime}[\mathrm{TPB}]$, where $k^{\prime}=k\left[\right.$ Catalyst ${ }^{n}$

b "No reaction detected" indicates [TPB'] data not statistically significant at a $95 \%$ confidence level. 3PB and 2 PB data verifies the lack of a significant reaction. 


\subsection{Internal References}

1. D. D. Walker, M. J. Barnes, C. L. Crawford, R. F. Swingle, R. A. Peterson, M. S. Hay, and S. D. Fink, "Decomposition of Tetraphenylborate in Tank 48H (U)", WSRC-TR-96-0113, Rev. 0, May 10, 1996.

2. M. J. Barnes, C. L. Crawford, C. A. Nash, and T. B. Edwards, "Task Technical Plan for Sodium Tetraphenylborate Decomposition Catalyst Identification Studies (U)", WSRC-RP-96-600, Rev. 2, June 20, 1997.

3. M. J. Barnes, C. L. Crawtord, and C. A. Nash, "Sodium Tetraphenylborate Catalyst Identification: Preliminary Studies Set 1 (U)", WSRC-TR-97-0060, March 6, 1997.

4. M. J. Barnes, "Sodium Tetraphenylborate Catalyst Identification: Preliminary Studies Set 2 (U)", WSRC-TR-97-0144, Rev. 0, March 6, 1997.

5. M. J. Barnes, "Sodium Tetraphenylborate Catalyst Identification: Phase A Statistical Design Studies (U)", WSRC-TR-97-0210, Rev. 0, July 22, 1997.

6. "Department of Energy Implementation Plan for Defense Nuclear Facilities Safety Board Recommendation 96-1 to the Secretary of Energy", In-Tank Precipitation Facility at the Savannah River Site, October 1996.

7. A. W. Wiggins, "Soluble TPB Decomposition and Catalysis" (U), HLW-TTR-97008, November 15, 1996.

8. D. D. Walker, "Calibration of Laboratory Glassware" (U), Manual L12.1, Procedure IWT-OP-009, Rev. 3, May 8, 1995.

9. M. J. Barnes and T. B. Edwards, "Copper Catalyzed Sodium Tetraphenylborate Decomposition Studies (U)", WSRC-TR-96-0351, November 7, 1996.

10. J. C. Marek, unpublished results.

11. V. Van Brunt, "Report on ITP History Test" (U), USC-FRED-PSP-RPT-09-1-005, University of South Carolina, July 21, 1997.

12. D. D. Walker, data contained in Laboratory Notebook WSRC-NB-95-23, p. 88.

13. M. J. Barnes, R. A. Peterson, R. F. Swingle and C. T. Reeves, "Sodium Tetraphenylborate Solubility and Dissolution Rates (U)", WSRC-TR-95-0092, March 7, 1995. 


\section{DISTRIBUTION}

Amerine, D. B., $704-56 \mathrm{H}$
Barnes, J. L., $704-\mathrm{S}$
Barnes, M. J., $773-\mathrm{A}$
Britt, T. E., $732-\mathrm{B}$
Carter, J. T., $704-25 \mathrm{~S}$
Cauthen, G. L., $241-119 \mathrm{H}$
Clark, W. C., $241-119 \mathrm{H}$

Crawford, C. L., 773-41A

Doughty, D. E., 704-56H

Eberlein, S. J., 704-56H

Eibling, R. E., 704-T

Elder, H. H. , 241-121H

Fink, S. D., 773-A

Fowler, J. R. , 704-Z

Hitchler, M. J., 992W-1

Hobbs, D. T. 773-A

Holtzscheiter, E. W., 773-A

Hsu, C. W. , 773-A

Hsu, R. H., 773-43A

Hyder, M. L. , 773-A

ITP Library (c/o A. G. Wiest), 241-119H

Jacobs, R. A., 704-T

Johnson, M. D., 704-56H

Keefer, M. T., 241-153H

Landon, L. F., 704-T

Lewis, B. L., 703-H

Lex, T. J., 719-4A

Lowe, P. E., 773-42A

Marek, J. C., 704-T

McCabe, D. J., 773-43A

McCullough, J. W., 703-H

Melton, W. L., 241-154H

Menna, J. D., 730-2B

Millex, M. S., 704-72S

Montini, M. J., 704-56H

Morin, J. P., 719-4A

Nash, C. A. , 676-1T

Nelson, L. M., 773-43A

Norkus, J. K., 730-2B

Papouchado, L. M., 773-A

Peterson, R. A., 676-T

Pettigrew, W. H., 704-S

Piccolo, S. F., 704-56H

Randa 11, C. T., 704-T

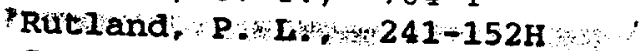

Satterfield, R. M. , 719-4A

Suggs, P. C., 703-H

Swingle, R. F., 773-A

Tamosaitis; W. L., 773-A

Taylor, G. A., 241-121H

Thomas, J. K., 730-2B

Van Pelt, W. B., 676-1T

Walkex, D. D., 773-A

Walker, W. C., 241-82H

Wiggins, A. W., $241-84 \mathrm{H}$

Wooten, A. L., 732-B

Wright, G. T., 773-A

IWT-LWG Files, 773-A

TIM (4), 703-43A 